\title{
Triamcinolone-assisted 3D-vitrectomy in diabetic vitreomacular traction
}

\author{
Vitrectomia 3D guiada por triancinolona na tração vitreomacular do diabetes
}

\author{
Otacílio de Oliveira Maia Júnior ${ }^{1}$ \\ Walter Yukihiko Takahashi ${ }^{2}$ \\ John Helal Júnior ${ }^{3}$
}

From the Retina and Vitreous Service, University of São Paulo Medical School - São Paulo - SP - Brazil, and São Rafael Hospital - Monte Tabor Foundation - Salvador (BA) - Brazil.

${ }^{1}$ Vitreoretinal Specialist at the Department of Ophthalmology, São Rafael Hospital, Monte Tabor Foundation, Salvador (BA) - Brazil.

${ }^{2}$ Head of the Vitreoretinal Service, Department of Ophthalmology, University of São Paulo Medical School São Paulo (SP) - Brazil.

${ }^{3}$ Assistant Professor at the Department of Ophthalmology, University of São Paulo Medical School - São Paulo (SP) - Brazil.

Corresponding Author: Otacílio O. Maia Jr. Serviço de Retina e Vítreo, Departamento de Oftalmologia Hospital São Rafael, Fundação Monte Tabor. Av. São Rafael, 2.142 - São Marcos - Salvador (BA)

CEP 41253-190

E-mail: omaiausp@uol.com.br

Recebido para publicação em 26.04.2007

Última versão recebida em 19.06.2007

Aprovação em 25.06.2007

The authors declare to have no financial interest in this study.

Nota Editorial: Depois de concluída a análise do artigo sob sigilo editorial e com a anuência do Dr. Ayrton Roberto Branco Ramos sobre a divulgação de seu nome como revisor, agradecemos sua participação neste processo.

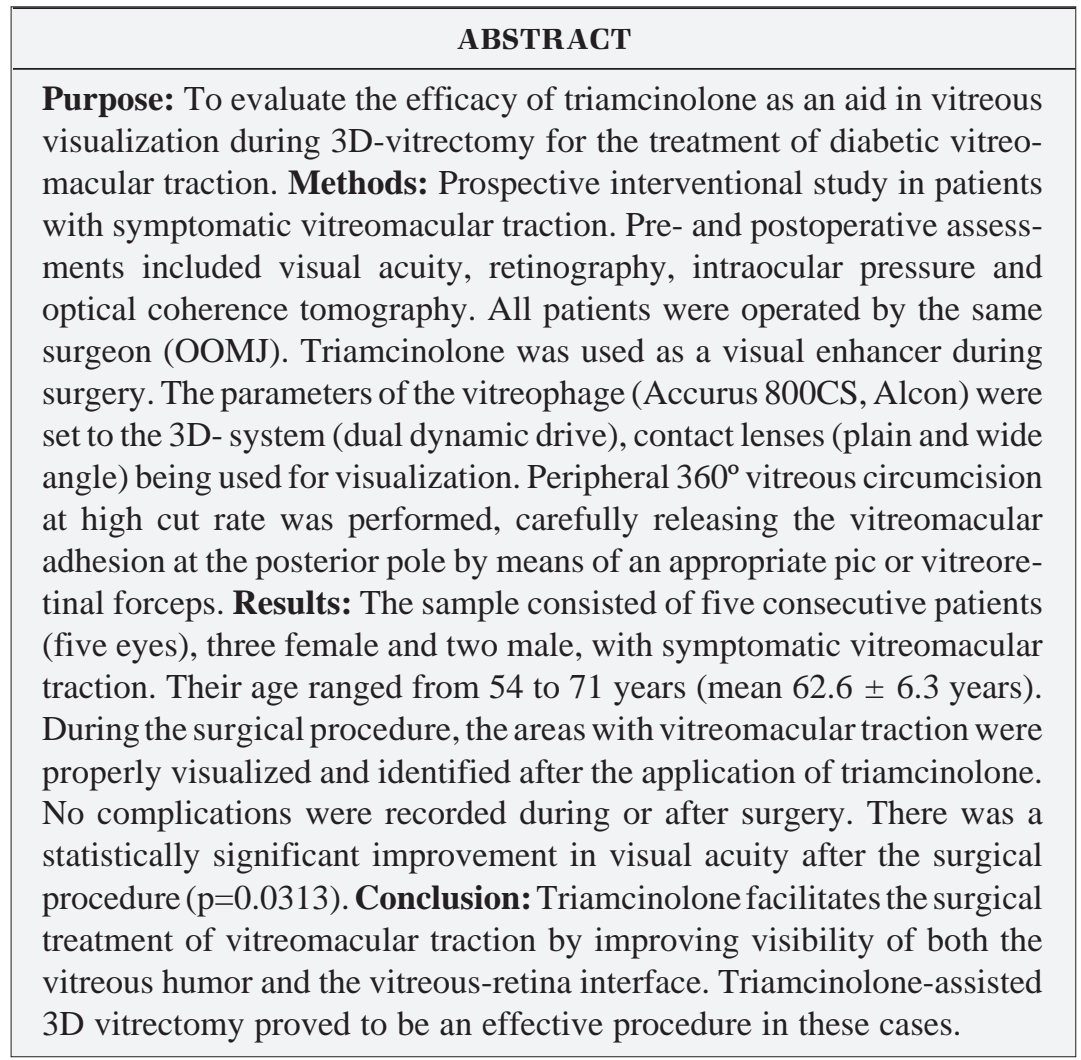

Keywords: Vitreous body/surgery; Vitrectomy/methods; Macula lútea; Triamcinolone; Postoperative complications; Tomography, optical coherence; Visual acuity

\section{INTRODUCTION}

The incomplete detachment of the posterior vitreous may affect the vitreous-retina interface and induce structural and functional changes of the retina secondary to the centripetal traction force exerted by the vitreous ${ }^{(1-2)}$. The macular region may become distorted and a minor traction detachment of the retina may occur ${ }^{(2-3)}$. Even though the separation of the posterior vitreous from the retina, in the area of abnormal adhesion, may occur spontaneously ${ }^{(4-5)}$, vitrectomy should be considered in cases of symptomatic vitreomacular traction with reduced visual acuity or metamorphopsia $^{(6-7)}$. Optical coherence tomography (OCT) shows the vitreous-retinal interface in detail, and may reveal structural alterations of the retina resulting from vitreomacular traction, thus helping in the diagnosis choosing an appropriate $\operatorname{approach}^{(8)}$. 
Table 1. Characteristics of patients with diabetic vitreomacular traction submitted to triamcinolone-guided 3D vitrectomy at the University of São Paulo Medical School General Hospital, São Paulo, Brazil - 2006

\begin{tabular}{|c|c|c|c|c|c|c|c|}
\hline Patients & $\mathrm{Age}^{*}$ & Sex & Panphotocoagulation ${ }^{+}$ & Preoperative VA $^{\circ}$ & Vitrectomy & Follow-up ${ }^{\square}$ & Postoperative VA $^{\circ}$ \\
\hline 1 & 54 & Female & 18 & $20 / 60$ & 20-Gauge & 9 & $20 / 20$ \\
\hline 2 & 63 & Male & 24 & $20 / 100$ & 25-Gauge & 6 & $20 / 25$ \\
\hline 3 & 65 & Female & - & $20 / 80$ & 20-Gauge & 3 & $20 / 30$ \\
\hline 4 & 71 & Female & 14 & $20 / 200$ & 25-Gauge & 3 & $20 / 30$ \\
\hline 5 & 60 & Male & 18 & $20 / 100$ & 25-Gauge & 6 & $20 / 30$ \\
\hline
\end{tabular}
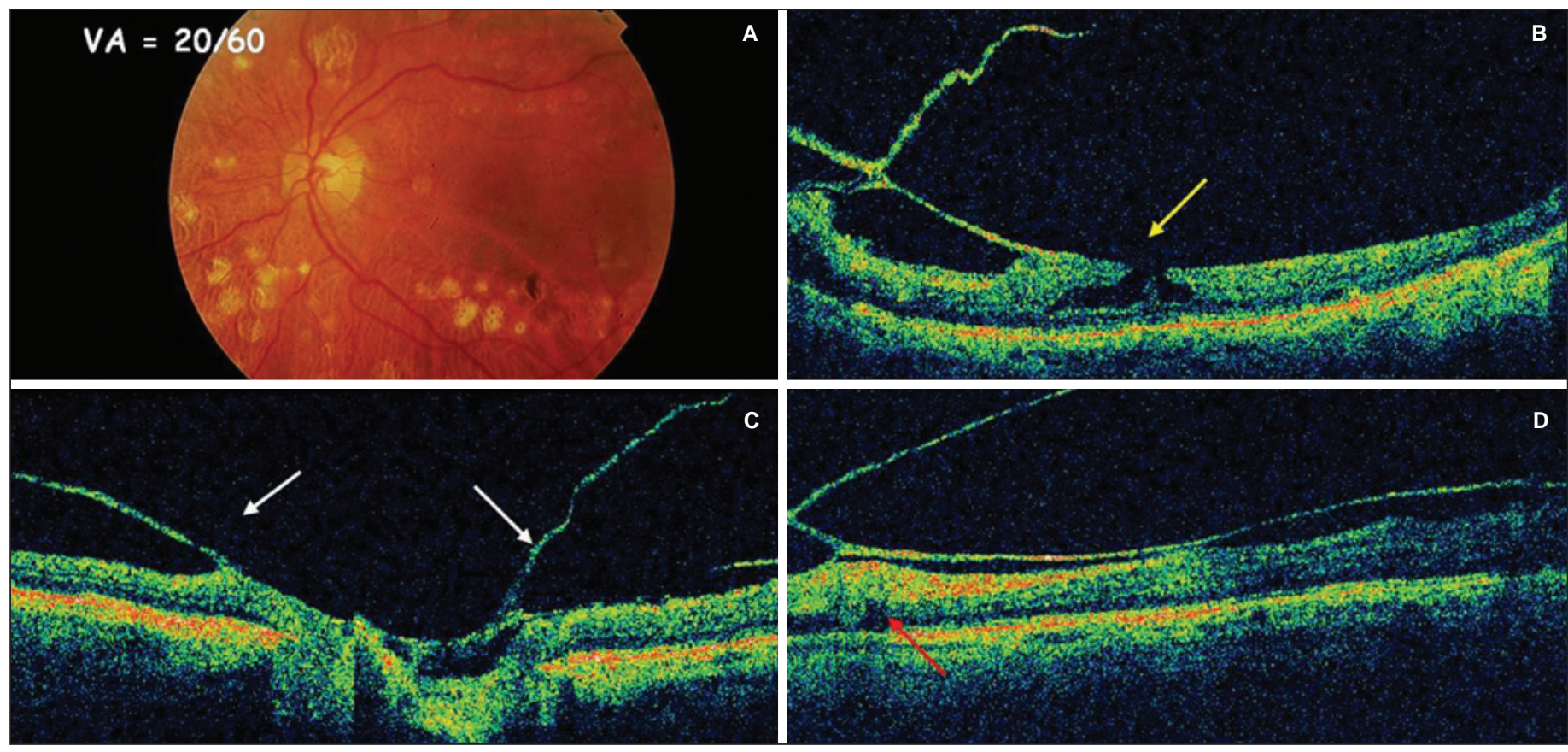

Figure 1 - Preoperative: patient 1,54-year-old, female, with diabetic retinopathy previously treated with panphotocoagulation by argon laser, with vitreomacular traction. Retinography of the left eye shows laser scars and a lamellar hole (A). Stratus OCT evidenced a lamellar hole with vitreomacular traction on the edge (yellow arrow) (B), incomplete vitreous detachment around the optic nerve (white arrow) (C) and an area of subretinal hyporeflectivity (red arrow) indicating a shallow tractional retinal detachment (D).

Despite advances in surgical instrumentation and techniques, the vitrectomy procedure continues to demand both skill and experience. The removal of the vitreous is a particularly challenging procedure, partly because of its transparency ${ }^{(9)}$. To assist in the visualization of the vitreous during vitrectomy, intraoperative triamcinolone acetonide was used. The triamcinolone acetonide-assisted pars plana vitrectomy technique has been previously described ${ }^{(10-11)}$, although not in vitreomacular traction; we consider its use in this indication as a useful tool for the success of the surgery and to decrease iatrogenic risks. The objective of this study is to evaluate the effectiveness of triamcinolone as an aid in vitreous visualization during vitrectomy for diabetic vitreomacular traction.

\section{METHODS}

Interventional case series of patients with symptomatic vitreomacular traction from the Department of Ophthalmolo- gy, University of São Paulo Medical School General Hospital, were submitted to a 20 - or 25-gauge vitrectomy and prospectively evaluated for a minimum period of 3 months. Exclusion criteria were: cataract, corneal opacity, glaucoma, vitreous hemorrhage and loss of follow-up.

Pre- and postoperative assessments included visual acuity (Snellen), retinography, Goldmann applanation tonometry and OCT. The images obtained with the Stratus OCT version 4.0 (Carl Zeiss Meditec) were taken at the macular thickness program with the cursor placed manually in the center of the fovea, whenever the foveal depression was visible.

All patients were submitted to vitrectomy performed by the same surgeon (OOMJ), between January and July 2006. During surgery, prior core vitrectomy was performed, and triamcinolone (Kenalog ${ }^{\circledR}$, Bristol-Myers Squibb Company) was then injected through a soft cannula, in a sufficient amount to stain the vitreous humor. The parameters of the vitreophage (Accurus $800 \mathrm{CS}$, Alcon) were set to the 3D system (dual dynamic drive), and contact lenses (plain and wide angle) were used for 


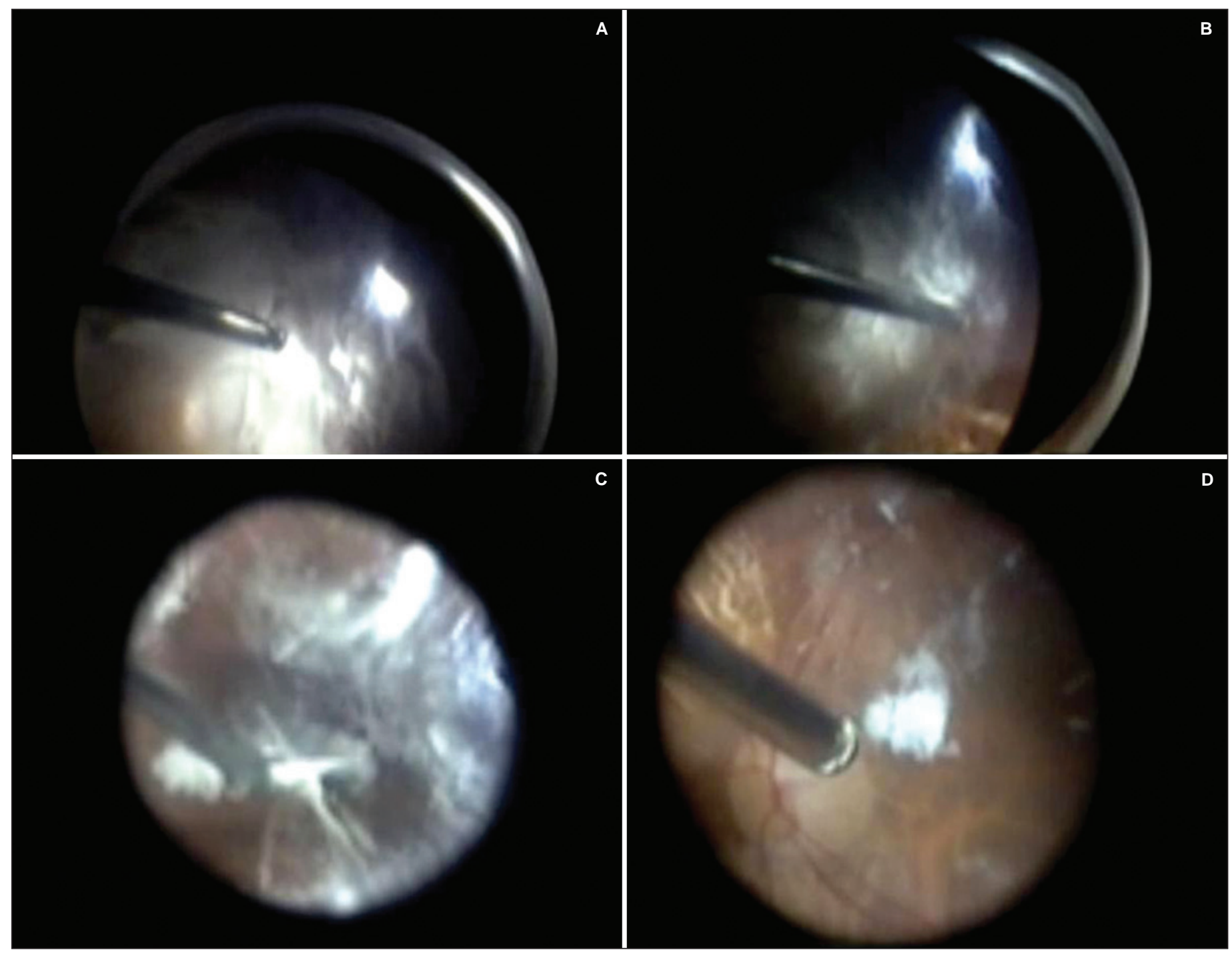

Figure 2 - Intraoperative. Triamcinolone-guided 3D-vitrectomy for diabetic vitreomacular traction (A). $360^{\circ}$ vitreous circumcision at high cut rate (B). Vitreomacular adhesion carefully released with a pic (C). Removal of remaining vitreous after tractions were released (D).

visualization. Initially, a $360^{\circ}$ vitreous circumcision at high cut rate was performed to avoid increasing macular traction by the adherent vitreous. After this initial approach, the vitreomacular adhesion was carefully released with a pic. Tighter adhesions were then removed with an appropriate vitreoretinal forceps. Upon removal of the vitreomacular tractions, a detailed inspection of both the posterior pole and the periphery was performed, in order to detect preexisting or iatrogenic ruptures. Air-gas exchange was performed as required.

Each variable was analyzed through descriptive statistics. For quantitative variables, this analysis included minimum and maximum values, mean and standard deviation. For qualitative variables, absolute and relative frequencies were calculated. The visual acuity measurement was converted to logMAR and analyzed through a non-parametric sign test. The level of significance used for the test was $5 \%$. The study was approved by the Institutional Review Board/ Research Ethics Committee of the University of São Paulo Medical School General Hospital and all the patients signed an Informed Consent Form.

\section{RESULTS}

The sample consisted of five consecutive patients (five eyes) with symptomatic vitreomacular traction. Three patients $(60 \%)$ were female and two $(40 \%)$, male. The age ranged from 54 to 71 years (mean $62.6 \pm 6.3$ years). All patients had type 2 diabetes mellitus, and $80 \%$ had diabetic retinopathy and had undergone panphotocoagulation with argon laser at least one year ago (Table 1).

Preoperative visual acuity ranged from $20 / 200$ to $20 / 60$ ( $\log$ MAR, 1.00 to 0.50 - mean $0.70 \pm 0.18)$. On OCT, all patients presented hyperreflective structures, marginal to the optical nerve and in the macular region, both sites corresponding to areas of vitreomacular traction. 

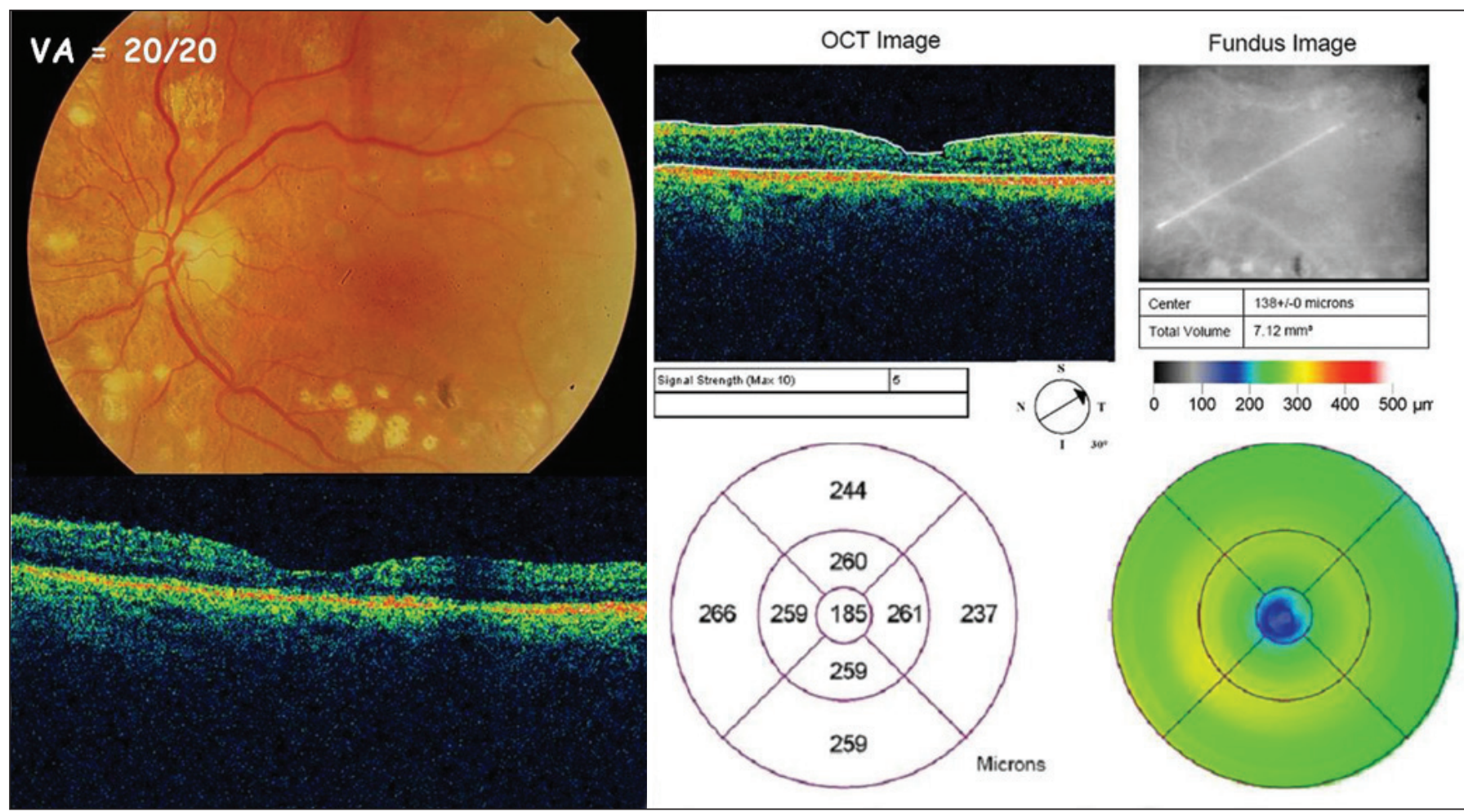

Figure 3 - Postoperative: patient showing visual acuity improvement 9 months after the surgical procedure. Stratus OCT evidenced macular structure recovery. Normal foveal thickness $(185 \mu \mathrm{m})$.

Two patients underwent a 20-gauge vitrectomy and three, 25 -gauge. During the surgical procedure, the areas with vitreomacular traction were properly visualized and identified after the application of triamcinolone. Air-gas exchange was not required in any of the patients. No complications were observed during or after surgery. Intraocular pressure increase was not detected throughout the follow-up period.

There was a significant improvement in visual acuity ( $\mathrm{p}=0.0313$ ) with measurements ranging, on the last follow-up visit, from 20/30 to 20/20 (logMAR 0.20 to 0.00 - mean $0.14 \pm$ 0.09). The follow-up period ranged from 3 to 9 months (mean $5.4 \pm 2.5$ months). One case was selected to illustrate the surgical procedure and the outcome (Figures 1,2 and 3).

\section{DISCUSSION}

Triamcinolone acetonide-assisted visualization of the vitreous has been reported as a helpful tool for surgeons performing procedures such as internal limiting membrane peeling or posterior vitreous separation ${ }^{(9-16)}$. However, this is the first study to describe the use of triamcinolone-guided 3D vitrectomy in the treatment of diabetic vitreomacular traction.

Anomalous posterior vitreous detachment results when the extent of vitreous liquefaction exceeds the degree of weakening of vitreoretinal adherence and traction is exerted at this interface. There are various causes for this imbalance between the degree of gel liquefaction and weakening of vitreoretinal adhesion $^{(17)}$. Systemic conditions, such as diabetes, induce biochemical and structural alterations in the vitreous ${ }^{(18)}$. In this study, all patients had diabetes mellitus and most of them had been previously treated with panphotocoagulation with argon laser. In addition to the underlying systemic disease, laser therapy may have played some role in the etiology of vitreomacular traction in these patients.

During vitrectomy for vitreomacular traction, the traction may increase in the areas with established vitreoretinal adhesion, worsening the visual prognosis. However, no intraoperative complications were observed during triamcinolone-guided 3D vitrectomy. The 3D technology provides flow control of the removed vitreous, adjusted both to the cutting speed and to the vacuum produced by a customized treadle. In addition, triamcinolone acted as a facilitator of the surgical procedure, by improving visibility of both the vitreous humor and the vitreous-retina interface. Therefore, triamcinolone-guided 3D vitrectomy proved effective in these cases. These findings warrant further studies to evaluate the long-term effects on retinal structure and retinal function.

\section{RESUMO}

Objetivo: Avaliar a eficácia da triancinolona como marcador vítreo na vitrectomia 3D para tratamento da tração vitreomacular do diabetes. Métodos: Realizou-se um estudo prospectivo intervencionista numa série de portadores de tração vi- 
treomacular sintomática. Na avaliação pré e pós-operatória foram realizadas a medida da acuidade visual, retinografia, pressão intra-ocular e tomografia de coerência óptica. Todos pacientes foram submetidos à vitrectomia pelo mesmo cirurgião (OOMJ). No intra-operatório, utilizou-se triancinolona como marcador vítreo. Os parâmetros do vitreófago (Accurus 800CS, Alcon) foram programados no sistema 3D (dual dynamic drive), sendo utilizadas lentes de contato (grande angular e plana) para visibilização. Realizou-se circuncisão vítrea periférica $360^{\circ}$ com alto corte, desfazendo cuidadosamente as adesões vitreomaculares no pólo posterior por meio de gancho ou pinças vítreo-retinianas adequadas. Resultados: A amostra foi composta por cinco pacientes (cinco olhos) consecutivos com tração vitreomacular sintomática. Três eram do sexo feminino e dois, do masculino. A idade variou de 54 a 71 anos (média de 62,6 $\pm 6,3$ anos). Durante o procedimento cirúrgico, os locais de tração vitreomacular foram identificados com boa visibilidade após aplicação da triancinolona. Não foram observadas intercorrências tanto no intra quanto no pós-operatório. Houve melhora estatisticamente significante na acuidade visual após procedimento cirúrgico $(\mathrm{p}=0,0313)$. Conclusão: A triancinolona tem ação facilitadora no tratamento cirúrgico da tração vitreomacular, por melhorar visibilização tanto do humor vítreo quanto da interface vítreo-retina. A cirurgia de vitrectomia $3 \mathrm{D}$, guiada por triancinolona, mostrou-se ser um procedimento eficiente nesses casos.

Descritores: Corpo vítreo/cirurgia; Vitrectomia/métodos; Macula lútea; Triancinolona; Complicações pós-operatórias; Tomografia de coerência óptica; Acuidade visual

\section{REFERENCES}

1. Hikichi T, Yoshida A, Trempe CL. Course of vitreomacular traction syndrome. Am J Ophtalmol. 1995;119(1):55-61.

2. Smiddy WE, Green WR, Michels RG, de la Cruz Z. Ultrastructural studies of vitreomacular traction syndrome. Am J Ophthalmol. 1989;107(2):177-85.
3. Yamada M, Kishi S. Tomographic features and surgical outcomes of vitreomacular traction syndrome. Am J Ophthalmol. 2005;139(1):112-7. Comment in: Am J Ophthalmol. 2005;140(4):765-6; author reply 766.

4. Kusaka S, Saito Y, Okada AA, Sasamoto M, Hayashi A, Ohji M, et al. Optical coherence tomography in spontaneously resolving vitreomacular traction syndrome. Ophthalmologica. 2001;215(2):139-41.

5. Carpineto P, Ciancaglini M, Aharrh-Gnama A, Agnifili L, Mastropasqua L. Optical coherence tomography and retinal thickness analyser features of spontaneous resolution of vitreomacular traction syndrome: a case report. Eur $\mathbf{J}$ Ophthalmol. 2004;14(1):67-70.

6. McDonald HR, Johnson RN, Schatz H. Surgical results in the vitreomacular traction syndrome. Ophthalmology. 1994;101(8):1397-402; discussion 1403.

7. Primiano Júnior HP, Nakashima AF, Maia Júnior OO, Bonanomi MT, Nakashima Y. Estudo da síndrome de tração macular vítreo-retiniana idiopática por meio da tomografia de coerência óptica: relato de casos. Arq Bras Oftalmol. 2007;70(1):143-7.

8. Larsson J. Vitrectomy in vitreomacular traction syndrome evaluated by ocular coherence tomography (OCT) retinal mapping. Acta Ophthalmol Scand. 2004;82(6):691-4.

9. Yamakiri K, Sakamoto T, Noda Y, Nakahara M, Ogino N, Kubota T, et al. Reduced incidence of intraoperative complications in a multicenter controlled clinical trial of triamcinolone in vitrectomy. Ophthalmology. 2007;114(2): 289-96.

10. Peyman GA, Cheema R, Conway MD, Fang T. Triamcinolone acetonide as an aid to visualization of the vitreous and the posterior hyaloid during pars plana vitrectomy. Retina. 2000;20(5):554-5.

11. Sakamoto T, Miyazaki M, Hisatomi T, Nakamura T, Ueno A, Itaya K, et al. Triamcinolone-assisted pars plana vitrectomy improves the surgical procedures and decreases the postoperative blood-ocular barrier breakdown. Graefes Arch Clin Exp Ophthalmol. 2002;240(6):423-9.

12. Doi N, Uemura A, Nakao K, Sakamoto T. Vitreomacular adhesion and the defect in posterior vitreous cortex visualized by triamcinolone-assisted vitrectomy. Retina. 2005;25(6):742-5.

13. Enaida H, Hata Y, Ueno A, Ishibashi T, Torii H, Sakamoto T. Visualization of the Cloquet canal during triamcinolone-assisted vitrectomy. Arch ophthalmol. 2004;122(10):1564-5.

14. Enaida H, Hata Y, Ueno A, Nakamura T, Hisatomi T, Miyazaki M, et al. Possible benefits of triamcinolone-assisted pars plana vitrectomy for retinal diseases. Retina. 2003;23(6):764-70.

15. Sonoda KH, Enaida H, Ueno A, Nakamura T, Kawano YI, Kubota T, et al. Pars plana vitrectomy assisted by triamcinolone acetonide for refractory uveitis: a case series study. Br J Ophthalmol. 2003;87(8):1010-4.

16. Furino C, Micelli Ferrari T, Boscia F, Cardascia N, Recchimurzo N, Sborgia C. Triamcinolone-assisted pars plana vitrectomy for proliferative vitreoretinopathy. Retina. 2003;23(6):771-6.

17. Sebag J. Anomalous posterior vitreous detachment: a unifying concept in vitreo-retinal disease. Graefes Arch Clin Exp Ophthalmol. 2004;242(8):690-8.

18. Sebag J, Buckingham B, Charles MA, Reiser K. Biochemical abnormalities in vitreous of humans with proliferative diabetic retinopathy. Arch Ophthalmol. 1992;110(10):1472-9. 